\section{Tuberculosis and War}

IN a recent paper on this subject (Paris méd., 1, 52 ; 1940), Dr. E. Rist, of Paris, remarks that war favours the extension and aggravation of tuberculosis not only in belligerent nations but also in neutral countries, owing to the economic disturbance caused by the blockade, the scarcity of indispensable articles due to the destruction of merchant shipping and the hindrances of all kinds offered to the transport of goods by land and sea. During the War of 1914-18, the mortality curve from tuberculosis, which had fallen from 1900 to 1914 , rose sharply from 1915 to 1918, and did not decline again until after the conclusion of peace. Among the numerous causes of an increase of endemic tuberculosis in war-time, one of the most serious is the rapid and wholesale evacuation of urban and rural populations to districts which are not sufficiently prepared to receive them, with the result that numerous healthy persons become infected with tuberculosis by those suffering from an active form of the disease.

Another factor leading to increase is the interruption of the most successful method of treatment of pulmonary tuberculosis, consisting in various forms of collapse therapy, especially artificial pneumothorax, caused by evacuation of patients to areas where there are no practitioners familiar with the technique. Other factors found to be responsible for the spread of tuberculosis are overwork, especially among those engaged in war industries of various kinds, under-feeding, as was illustrated in Denmark during 1914-18, and mental worry, the importance of which was emphasized by Laennec long ago. In conclusion, Dr. Rist, while admitting the necessity of an ample supply of tuberculosis experts in the armed forces, emphasizes the importance of restoring to civil practice a large number of them who are employed on quite unsuitable duties.

\section{British Museum (Natural History)}

Lecture tours in the British Museum (Natural History) on Saturdays at 3 p.m., and on the first Sunday in each month at 3 p.m. have been arranged. London museums are re-opening their doors, and although many treasures have had to be moved away to safety from the Natural History Muweum, their places have been filled to some extent by special exhibitions and new grouping. Two of the galleries are being used for a special exhibition to show Nature in the service of man. The exhibits illustrate the animals and plants from which our most important textiles are produced; sources of oil, animal, vegetable, and mineral, and some of the industries in which the various oils are needed; materials from which cosmetics and surgical requisites are prepared; the use made of spiders' webs and the origin of domestic breeds of poultry, cattle, pigs, etc. There is a section showing the animals particularly useful in war, such as white mice, canaries, reindeer, and Airedale dogs. Another gallery which has been proving a great attraction during the few weeks of limited opening is the Whale Hall, where a full-size model of a Blue Whale
92 feet long is on view-a treasure certainly, but much too large for evacuation !

\section{Night-Shining Eyes}

Most people are familiar with the greenish gleam which shines from the eyes of a cat when a beam of light is directed upon them at night, and are aware that the glow can be seen only when the observer's line of vision is closely parallel with the beam of light. The phenomenon has been investigated in many animals by E. P. Walker, assistant director of the National Zoological Park of the Smithsonian Institution, and his results are referred to in the current Year Book of the Institution. The apparatus used in the tests was a reflecting head lamp, similar to a hand torch, worn on the forehead and connected with a three-cell battery in his pocket. The best results were obtained with a beam of moderate intensity, the effect of an intense beam being to make the glow less conspicuous or entirely to prevent its appearance. The shining is due to reflection from some surface in the eye, but its colour and character vary with the kind of animal. Colour ranges ran from silvery to blue-green, pale gold, reddish-gold, brown, amber and pink, and while most resembled reflection from a burnished metal surface, those of crocodiles and alligators gave the observer the impression of gazing into "a brilliantly glowing pinkish opening in a dull-surfaced bed of coal".

In the case of glowing eyes, the appearance is as if one looked through the pupil of the eye and saw reflection from the surface of the retina, but where the gleam was metallic in character there was no impression of looking into the interior of the eye. In the latter case, however, a difficulty arose because in most cases the reflection disappeared at a distance closer than from eight to twenty feet, so that the actual reflecting surface could not be determined. In some forty species of mammals and reptiles tests were made with red and blue coloured beams of light, but these made little change in the reflected gleam except to add a corresponding tinge of red or blue, a result which confirms the suggestion of simple reflection without any real animal light. To some degree there is a family resemblance in the character of the gleams, for most rodent eyes shine dully in brown, hazel or amber, although in porcupines the reflection is brilliantly silver. No shine was obtained from the eyes of higher apes or monkeys and no proof of the alleged shining of human eyes, yet, curiously enough, the most brilliant reflections of all were from the eyes of two of the lemurs, the slow loris and the potto.

\section{Ethnological Reconnaissance in New Guinea}

Mucr of the Mandated Territory of New Guinea is still uncontrolled, and even unexplored. Notwithstanding the difficulties of the country, the policy of exploration with a view to control is pursued with as little intermission as circumstances allow and has made substantial additions to knowledge in the information collected relating to the culture of previously unvisited or unknown peoples of the interior, notably in the regions adjacent to Mt. 
Hagen. A recent report to Sir Walter McNicoll, administrator of the Mandated Territory, by Mr. J. L. Taylor, assistant district officer, records the results of a patrol carried out by him in unexplored country westward from Mt. Hagen to the border of Dutch New Guinea, and northward towards the southern tributaries of the Sepik River during March 9, 1938-June 19, 1939. 'The area surveyed consisted of some 20,000 square miles, and was found to be for the most part of temperate climate, such as might be suitable for European oceupation. The future of the country traversed is said to lie in agriculture and pig-raising.

Large numbers of natives were encountered, most of whom appear to have been friendly, though on more than one occasion the patrol was attacked and suffered some casualties. Among natives to the north-west of Mt. Hagen, who had not previously seen a white man, the members of the patrol were regarded as spirits of the dead returned to earth. One of them, while taking observations from a tree, received the offering of a pig and was asked to ascend to heaven. In another village, the women were kept at a distance in the belief that they would die if they beheld these spirits. Among the more remarkable features in the culture of the peoples encountered, of which some particulars are given in a dispatch from the Canberra correspondent of The Times in. the issue of March 26, is a system of deep drains or sunken roads, in the form of an elaborate complex of trenches, which serves both for defence and in cultivation as an effective drainage system, or as a protection against the ravages of pigs. Another romarkable culture trait is the use of wigs of human hair, made by professional wig-makers. Each man, it is said, aimed at having at least one wig made of his own hair. The tribes of the area were found to be keen traders, the most important and much sought after commodity being salt prepared frcm wood burnt after saturation in salt-springs.

\section{Archæological Investigations in Jerusalem}

Excavation of the remains of certain of the ancient walls of Jerusalem carried out by Mr. C. N. Johns on behalf of the Department of Antiquities has produced results of considerable archæological interest and historical importance. These results include the establishment of a chronological sequence in the remains of these ancient walls, which carries back to pre-Herodian times-certainly to the Maccabees and possibly even to the days of Nehemiah, although the evidence for the latter is archæologically undated. A further result is the confirmation of a tentative identification, made in the seventies of the last century, of the so-called Tower of David with Phasael, the third of the three towers described by Josephus as erected by Herod the Great. The systematic exploration of the site was made possible by the demolition of the Turkish barracks under the British occupation, and was undertaken by the Department of Antiquities in 1934 through the direct personal interest of Sir Arthur Wauchope, then High Commissioner.
The excavation, as described in a dispatch from the Jerusalem correspondent of The Times in the issue of March 23, has laid bare the old wall inside and parallel to the present north and west walls of the Citadel as reconstructed by the Crusaders and Mamelukes. This fragment of the old wall consists of three towers, Phasael and those named respectively by the excavators the Corner Tower and the South Tower, and their connecting curtain walls. The curtain between Phasael and the Corner Tower is of erude chalky stone solidly laid without mortar on the native rock scarp. Stratified remains of pottery suggest that this may go back to Jonathan Maccabæus; but in fact it incorporates an even earlier and clumsier wall, as previously mentioned, archæologically undated. The Maccabæan wall was partially demolished shortly after its erection, in a battle, presumably during the sieges by one or other of the Antiochus dynasty, of which the relics are seen in iron and bronze javelin heads and stone ballista balls. There is now evidence that after repairs it was reconstructed in the remarkable protective works of Herod, in which the tower Phasael was the strongest and most striking, rising from a cube of solid masonry, measuring $68 \mathrm{ft}$. on each side, in two stages to a height of $155 \mathrm{ft}$. In addition to their intrinsic interest, these discoveries will tend to throw light on other problems of the character and appearance of the Holy City at the opening of our era.

\section{Trotula and the Ladies of Salerno}

Is a paper read before the Section of the History of Medicine of the Royal Society of Medicine on January 10, Dr. H. P. Bayon stated that several contemporary writers maintained that a fictitious Trottus was the author of "De passionibus mulierum", which was usually ascribed to Trotula of Salerno, a matron mentioned in the text of most manuscript copies and therefore a definite person. Whether she wrote or compiled the chapters "De ornatu mulierum" is not ascertained, but a study of early manuscript texts dealing with cosmetics seems to afford some clue. The gynæcological chapters are notable because of the recommendation of the support of the perinæum in childbirth and the primary suture of the perinæum. The many manuscript copies, printings and literary allusions concur in showing the appreciation which Trotula enjoyed during the twelfth to sixteenth centuries.

The references in the text of Trotula's work to Saracens, many drugs from the East, the avoidance of magical formulæ and hagiology, together with the description of alchemical manipulations, indicate the personal influence of Moslem and Hebrew physicians ; in other Salernitan writings, quotations from the Old Testament are preferred. It is recorded that Costanza of Salerno lectured on medicine during the reign of Giovanna I of Anjou (1326-82); she was probably the first woman professor. The decline of the College of Salerno must have occurred after its destruction in the sack of the town in 1194. In academical teaching Salernitan doctrines were replaced by dialectic scholastic medicine, but the 